\title{
TAXONOMICAL STUDIES OF FAMILY SIGNIPHORIDAE (Chalcidoidea) in Egypt
}

\author{
SHAABAN ABD-RABOU \\ Plant Protection Research Institute, ARC, Dokki, Giza, Egypt.
}

(Manuscript received 23 October 2011)

\begin{abstract}
Family: Signiphoridae (Chalcidoidea) is primarily hyperparasitoids on scale insects, whiteflies and mealybugs through other Chalcidoidea. Several species are primary parasitoids of armored scales and mealybugs. The present work dealt with the members of this family as to exist in Egypt. The results indicated that family Signiphoridae has five species, i.e. Chartocerus nigra (Ashmead), Chartocerus subaeneus (Forester), Signiphora fax Girault, Signiphora flavella Girault and Thysanus sp. Also, the constructed key for the Egyptian species is included.
\end{abstract}

\section{INTRODUCTION}

The Signiphoridae (Chalcidoidea) is a small family of Chalcidoidea containing 76 described species in four genera (Noyes 2003). Signiphoridae is minute parasitic wasps that are about $0,5-2 \mathrm{~mm}$ in length. The body is black or brownish, rarely with yellowish areas. The antenna are modified into 2-4 short, ringlike funicle segments followed by a long unsegmented clava. The scutellum is shaped like the metanotum (transverse and like a band). The mesonotal postphragma is very large, extending deeply into the gaster. It has a stout, flattened body and a long marginal fringe on the fore and hind wings(Woolley1997 and 1988). This family is primarily hyperparasitoids on scale insects, whiteflies and mealybugs through other Chalcidoidea. Several species are primary parasitoids of armored scale insects. Most are ectoparasitoids, although endoparasitoids are known. Some species are also known to be primary ectoparasitoids in the puparia of the dipterous families Chamaemiidae and Chloropidae, whereas others have been recorded as primary parasitoids of mealybugs (Rozanov, 1965).

This family was studied taxonomically by many workers Nikol'skaya (1950), Rozanov (1965), Hayat (1970 and 1976) and Hayat and Subba Rao (1986), Woolley 
(1988) and Noyes (2003). While in Egypt Abou-Elkhair (2001), Abd-Rabou (2006) and EI-Serwy et. al. (2007) dealt with this family

Aim of the present work is to study family Signiphoridae as well as developing a key of the species that exist in Egypt.

\section{MATERIALS AND METHODS}

Infested crops with armored scale insects, soft scale insects, mealybugs, whiteflies and psyllids were examined in the field, using a pocket lens during 20092011. Parts of the plant from different crops were collected and placed separately in paper bags for further examination in the laboratory. Material were kept in a wellventilated container until the emergence of any parasitoids. Identification of parasitoids was carried out by examining mounted adults in Hoyer,s medium and Card specimens according to the methods of Abd-Rabou (2002) and (Noyes (1982), respectively.

\section{RESULTS AND DISCUSSION}

Family Signiphoridae is represented by 5 species in Egypt: Chartocerus nigra (Ashmead), Chartocerus subaeneus (Forester), Signiphora fax Girault, Signiphora flavella Girault and Thysanus sp. (Table,1).

\section{Chartocerus nigra (Ashmead)}

Diagnosis: Polished black, impunctate, but with a decided seneous tinge in certain lights. Antennae brown-black (Table,1). Legs black, the anterior and middle tibae brownish, their tips and all tarsi white. Wings with the basal half or more fuliginous, the apical half or less hyaline. The marginal cilia of the fore wing are very much shorter, moderately short, very much shorter than the wing's greatest width (the length about a fourth or less of the wing's greatest width) and slightly shorter than the longest marginal cilia of the posterior wings; the fuscous area of the fore wing extends less farther distad (proximal third of the wing clouded), only to the distal third of the marginal vein but, however, the apical third of the wing may be slightly embrowned; the setae on the venation are more numerous, on the submarginal vein at least two, but on the marginal but six (not counting several very minute ones) and on the stigmal but one which is not apical.

Material examined : : $12 q+$, Qalyubiya, 15. X. 2009, ex. Chrysomphalus aonidum (L.) (Hemiptera : Diaspididae) on Citrus sp. 


\section{Chartocerus subaeneus (Forester)}

Diagnosis: The body shining black, antennae dark brown, eyes and ocelli black all tarsi yellowish, fore tibia pale, middle and hind tibia black in proximal half and pale distally, other segments of all legs black. Fore wing with alternating, broad hyaline and dark bands. Longest marginal cilia $1 / 2-2 / 3$ width of disc. Submarginal vein $3 / 4$ to nearly as long a marginal vein, bearing 2 setae and 13 bullae . Marginal vein bearing 4 long setae along anterior margin and 4-5 short ventral setae, stigmal vein about $1 / 5$ length of marginal vein , bearing single setae an 3 discoid sensilla. Costal cell bearing single dorsal seta. The medial denticles of the male genitalia are robust,curved and long, extending approximately half the length of the digiti and they are inserted on a strongly sclerotized region between the bases of the digiti middle and hind tibiae are black in proximal half.

Material examined : 10ㅇ, Behira , 17. XI. 2009, ex. Maconellicoccus hirsutus (Green) (Hemiptera : Pseudococcidae) on Hibscus sp.

\section{Signiphora fax Girault}

Diagnosis: General color dark or sooty brown, varying to brown, the thorax (dorsal aspect) marked with lemon yellow, excepting the pronotum and cephalic two-thirds of the mesoscutum, the yellow band thus moderate in width. When brown, the abdomen is lighter at tip. Fore wings smoky out to the end of the venation, the smoky area, as usual, lighter proximal. Legs variable, brown in dark specimens, with the knees, tips of tibiae and all of tarsi pallid yellowish; in light.

Material examined : There is no material collected during the present work.

Remark: This species was recorded in Egypt by Abou-Elkhair (2001).

\section{Signiphora flavella Girault}

Diagnosis: Abdomen suffused with orange,especially along each side of the middle; The stigmal vein forms a less regular and shorter concave curve, along its inner margin, with the apex of the inner margin of the marginal vein, but it is convex instead of concave at its point of origin. The fore wings are distinctly narrower but with the marginal cilia as long in proportion (long, graceful, distinctly longer than the greatest width of the wing). Otherwise the same in all visible details, except the wings, which are nearly similarly embrowned, but less deeply; also the antennal club (Table,1) is dusky at tip or distal fifth instead of being wholly dusky. The pedicel of the antenna is noticeably shorter and stouter, while the antennal club is noticeably shorter.

Material examined : 8$+q$, Qalyubiya, 20. IX. 2011, ex. Hemiberlesia rapex (Comstock) (Hemiptera : Diaspididae) on Citrus sp.

Hosts: Hemiberlesia rapex (Comstock), 


\section{Thysanus sp.}

Diagnosis: Having 3-dentate mandibles, pronotum as long as mesoscutum, basitarsi of middle legs as long as tibiae and a comparatively slender habitus. The subgenital plate with its anterior margin concave, posterior margin with a notch and a small lobe in middle, antero-lateral apodemes present may be taken as a new generic character.

Material examined : : 5 $+\uparrow$, Giza, 11.IV. 2009, ex. Pulvinaria tenuivalvata (Newstead) on sugar cane.

Hosts: $P$. tenuivalvata (Hemiptera: Coccidae)

\section{Key to the Signiphoridae species in Egypt}

1. Mandibles bi-dentate; pronotum half or less as long as mesoscutum; basitarsus of middle leg clearly shorter than tibia 2

-Mandibles tri-dentate; pronotum as long as mesoscutum; basitarsus

of middle leg as long as tibia; subgenital plate with anterior margin concave, posterior margin with a notch and a small lobe in middle, antero-laterial apodemes present Thysanus sp.

2. Funicle 3 -segmented $\ldots \ldots \ldots \ldots \ldots \ldots \ldots \ldots \ldots \ldots \ldots \ldots \ldots \ldots \ldots \ldots$

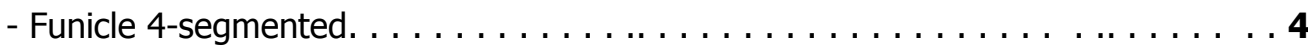
Signiphora fax

- Abdomen suffused with orange specially along each side of the middle. Signiphora flavella

4. All tarsi white, longest marginal cilia $1 / 4$ width of disc. Chartocerus nigra

- All tarsi yellowish, longest marginal cilia $1 / 2-2 / 3$ width of disc. Chartocerus subaeneus 
Table 1. Female antennae of the Egyptian genera of family Signiphoridae ( Figs after Hayat, 1970)

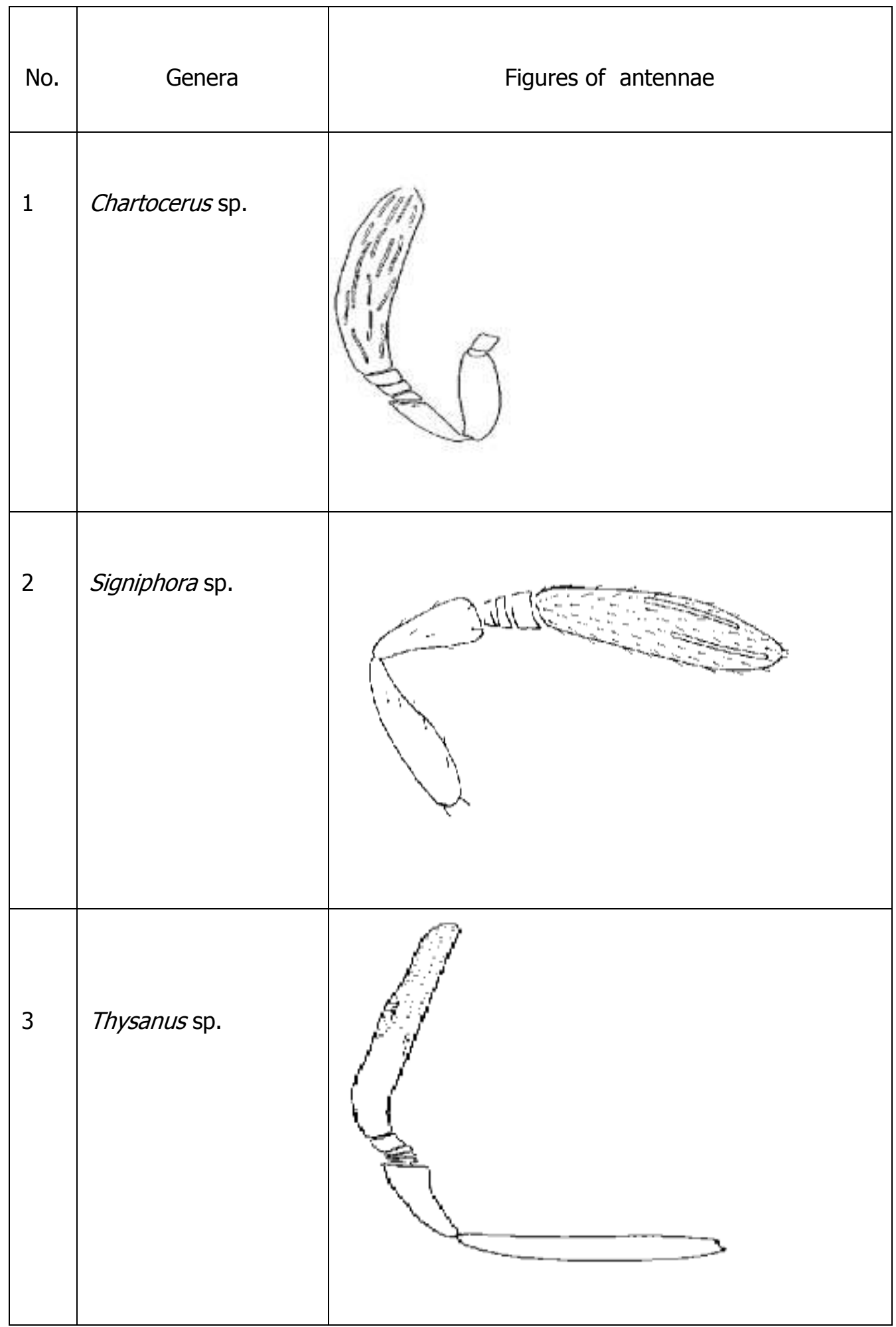




\section{REFERENCES}

1. Abd-Rabou, S. 2002. Revision of Aphelinidae (Hymenoptera) from Egypt. Second International Conference, Vol. of Plant Protection Research Institute, Vol. (1): 262-290.

2. Abd-Rabou, S. 2006. Hymenopterous parasitoids as a bioagent for controlling homopterous insects in Egypt. Egypt. Adv. Agric. Res. In Egypt, Vol. (6) 1: 1-65.

3. Abou-Elkhair, S. 2001. Scale insects (Hemiptera: Coccidae) and their parasitoids on ornamental plants in Alexandria, Egypt. Entomologica bari, 33(1999): 185-195.

4. EI-Serwy, S.A. , E. Guerrieri and G.A. Evans. 2007. The parasitoid complex of the red-striped soft scale, Pulvinaria tenuivalvata (Newstead) (Hemiptera: Coccidae) and its long-term effect on the scale on sugarcane in Egypt Proceedings of the XI International Symposium on Scale Insect Studies. Pp.217-227.

5. Hayat, M. 1970. Studies on the genera of the family Signiphoridae (Hymenoptera: Chalcidoidea) recorded from India. Entomophaga, 15(4):396-298 .

6. Hayat, M. 1976. Some Indian species of Chartocerus (Hym.: Chalcidoidea: Signiphoridae). Oriental Insects 10(2):162.

7. Hayat, M. and B. R. Subba Rao. 1986. Family Signiphoridae. (In: Subba Rao, B.R.; Hayat, M. (Eds) - The Chalcidoidea (Insecta: Hymenoptera) of India and the adjacent countries. Part II.) Oriental Insects, 20:140.

8. Nikol'skaya. 1950. Represen Latives of the family Signiphoridae [Hymenoptera: Chalcidoidea] in the fauna of the U.S.S.R. Dokl. Akad. Nauk. SSSR.,75, 319-320.

9. Noyes, J. S. 1982. Collecting and preserving chalcid wasps (Hymenoptera: Chalcidoidea). Journal of Natural History, 16: 315-334.

10. Noyes, J. S. 2003. Universal Chalcidoidea Database. World Wide Web electronic publication. www.nhm.ac.uk/entomology/chalcidoids/index.html .

11. Rozanov, I. V. 1965. Review of the genera of parasitic Hymenoplera of the family Signiphoridae (Hymenoptera: Chaleidoidea). Ent.Obozr, Moscow, 44, 866-884.

12. Woolley, J. B. 1988. Phylogeny and classification of the Signiphoridae (Hymenoptera: Chalcidoidea).- Systematic Entomology 13: 465-501.

13. Woolley, J. B. 1997. Chapter 18. Signiphoridae. In: Gibson, G.A.P., Huber, J.T. and Woolley, J.B.(eds). Annotated keys to the genera of nearctic Chalcidoidea (Hymenoptera). NRC ResearchPress, Ottawa, Ontario, Canada. pp. 693-699. 


\section{SIGNIPHORIDAE دراسات تقسيمية لعائلة}

فى مصر (Chalcidoidea)

$$
\text { شعبان عبد ريه }
$$

معهُ بحوث وقاية النباتات - مركز البحوث الزراعبة - الدقي- جيزة - مصر

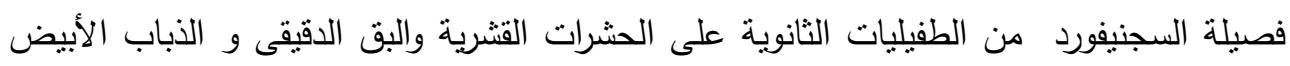
وحديثا يعتبر البعض منها من الطفيليات الأولية للبق الدقيقى و الحشرات القثرية المسلحة. هذا العمل يتضمن التعرف على الأنواع المتواجدة لهذه الفصيلة فى مصر ـ وقد أتضح من النتائج أن هذه الفصيلة الفئل تحتوى على خمسة أنواع بالأضافة الى عمل مفتاح تصنيفى للتعرف عليها. 